\title{
CEO Pay-Performance Sensitivity: A Multi-Equation Model
}

\author{
Rebecca Abraham, Judith Harris, Joel Auerbach \\ Huizenga School of Business, Nova Southeastern University, Fort Lauderdale, USA \\ Email: Abraham@nova.edu, harrisj@nova.edu, jauerk@gmail.com
}

Received 25 May 2014; revised 28 June 2014; accepted 13 July 2014

Copyright (C) 2014 by authors and Scientific Research Publishing Inc.

This work is licensed under the Creative Commons Attribution International License (CC BY). http://creativecommons.org/licenses/by/4.0/

(c) (i) Open Access

\section{Abstract}

This study examines the variables influencing CEO compensation in the technology sector using both exclusively exogenous and interchangeably exogenous and endogenous variables. The study was confined to a single industry to isolate industry compensation practices which may be smoothed out in multi-industry studies. Multiple equations in a vector autoregressive model were used to explain compensation in recognition of the endogeneity of variables such as sales growth, stock returns and net income. Using US firms listed on the NASDAQ, we find that CEO compensation (measured separately as salary only, stock option grants only and total compensation from all sources) to be significantly explained by firm size, the ability to reduce debt, the ability to fund growth, net income and personal characteristics. CEOs are rewarded for achieving profitability. While there is an expectation of innovation in the technology sector with research and development expenditure increasing both sales and stock returns, such innovation only contributes to CEO compensation if it is translated into rising net income in an environment of debt-reduction. Further, CEOs are rewarded for implementing disruptive technology as a competitive strategy. The ability to fund growth is pertinent for the technology sector which may be restricted in its access to debt. Increases in age, tenure and the existence of celebrity status of the CEO led to increased compensation underscoring the importance of personal characteristics.

\section{Keywords}

CEO Compensation, Pay-Performance Sensitivity, Technology, Multi-Equation, Accounting Measures

\section{Introduction}

The recent escalation of CEO pay has received much attention in both the popular press and in the academic li- 
terature (see Dong and Ozkhan [1], for a review). Frydman and Jenter [2] document a forty-year increase in pay with the highest annual growth rates reaching $10 \%$ in the 1990s regardless of firm size. This phenomenon has spurred debate as to whether such compensation is justified, i.e. does the performance of these executives merit the sharp increases in compensation? In response to this question, an extensive body of academic literature has been set forth to investigate the pay-performance link primarily in US firms. Agency theory has provided the theoretical basis for such examinations. The principal-agent model separates ownership by the shareholders and control by managers. Managers may act in their own self-interest contrary to the best interests of the shareholders. They may engage in risky projects that promise immediate payoffs to the detriment of future performance, reward themselves with perks, or undertake wasteful expenditures. Therefore, managerial compensation must be based on corporate performance so that managers have a personal stake in the long-term financial health of their firms, which in turn renders them more likely to undertake measures that promote financial wealth (Core et al., [3]; Jensen and Meckling, [4]). Empirically, conflicting results have emerged in studies of the pay-performance link (see O’Reilly and Main [5], for a review). On the one hand, certain studies have found that increases in stock returns explained higher CEO pay (Abowd and Kaplan [6]; Devers et al. [7]; Jensen and Murphy [8]; Main et al. [9]; Ozkan [10]; Vafeas [11]). Other studies, conclude that intervening variables such as board control of CEO compensation contracts (He and Conyon [12]; Werner et al. [13]), CEO duality whereby the CEO is the Chairperson of the Board (Cyert et al. [14]; Goyal and Park [15]), or antitakeover provisions (Borokhovich et al. [16]) explain CEO compensation rather than performance. Yet another set of studies find no relationship between firm performance and CEO pay or that weak firm performance results in higher CEO pay (Fligstein and Choo [17]; Kerr and Bettis [18]).

This study advances two reasons for the conflicting evidence in favor of a pay-performance link. The first reason is the failure to structure samples by industry. The sparse evidence indicates that industry classification may significantly explain executive compensation. Cole and Mehran [19] observed that in privately-held firms, the industry classification of manufacturing firms, transportation firms, wholesale trade, retail trade, insurance and real estate and professional services firms decreased executive compensation. Yet, there was no attempt to link pay to performance within a single industry, which would indicate the performance measures that are relevant to that industry. This study attempts to address this gap in the literature by examining the pay-performance relationship for CEO pay in the technology sector. Technological competitiveness is based upon the ability to produce a stream of products that meet a succession of market needs. It is driven by research and development expenditure that is allocated appropriately so that the aforementioned stream of new products is realized, rather than the continual expenditure of resources on ideas that never materialize into products. In this regard, we support a utilitarian expenditure of resources. Credit availability is particularly relevant to this industry. At their inception, firms in high-technology rely on the investment of venture capitalists. Over time, they may seek more traditional sources of funding from banks or finance companies. As a measurable performance indicator, the Credit Score may become a relevant gauge of credit availability for expansion. In fact, Cole and Mehran [19] observed that the Dun and Bradstreet Credit Score significantly explained executive compensation for a sample of small, privately held firms. Therefore, industries may have specific characteristics that may affect the variation in executive compensation, so that it is worthwhile to structure a sample by industry. Industry-specific studies are further justified on grounds that technology products are particularly unique in terms of their rapid speed of life cycle, high economies of scale and the "all or nothing" affect of consumer market behavior. They have a large initial outlay for discovery cost (either research or patents buying), a low expansive variable cost and are particularly vulnerable to subsequent disruptive technologies. Averaging across all industries will typically dampen if not lose the effect on performance or on compensation by this set of characteristics in any one industry. The second reason is that with the exception of a single study (Callan and Thomas [20]), empirical investigations have consisted of single-equation examinations. Typically, multiple regressions are conducted of executive compensation on firm performance measures (stock return, return on equity, return on assets, sales and net income) supplemented with CEO characteristics (tenure, career path, years as CEO) and firm size. The endogeneity of firm performance measures is not taken into account. Stock returns are dependent upon the stock's beta coefficient and the market risk premium in a Capital Asset Pricing Model framework (Fama and French [21]). They may also be related to retained earnings and revenue growth. Likewise, return on equity, return on assets and net income are based on net profit (revenue-fixed costs-variable costs-selling, general and administrative expenses). A change in any of these expense categories affects net income and in turn, returns on equity or return on assets which may yield positive or negative performance relationships with executive com- 
pensation. Accordingly, we propose a multi-equation approach which employs vector autoregression to explore the paths from accounting variables to firm performance measures, and in turn, to executive compensation. Likewise, we attempt to find the significance of each leg of the path from cost of goods sold to operating income to CEO compensation. Callan and Thomas [20] created three multiple regression equations describing the effects of firm performance measures on executive compensation, financial performance and corporate social responsibility. While each equation captured the influence of performance criteria on the outcome variables, the multiple regression methodology does not reveal paths of more than 2 variables. For example, the impact of industry group on corporate social responsibility and in turn, corporate social responsibility on executive compensation may be obtained through successive regressions. However, there was no single path linking industry group with corporate social responsibility to executive compensation, so that the aspect of social responsibility that is influenced by industry group could not be isolated in its influence on executive compensation. This study's employment of vector autoregression overcomes this limitation.

\section{Review of Literature}

\subsection{Theories of Innovation}

The Schumpeterian Theory of Innovation views innovation as the rejuvenation of the natural progression of the product life cycle (Schumpeter [22]). Products move through a product life cycle with high initial sales as the product gains market acceptance, flat sales as the product matures, and decline in sales and costs leading ultimately to obsolescence. Innovation disrupts this process with a new product with its own life cycle. In this respect, innovation is the production of a succession of new products. A related issue is that of cost. Given that each new product has an independent life cycle, it generates its own long run average cost curve which may or may not reach an optimal minimum over the life of the product. Any forecast of long-run average cost must be based on the cost of factor inputs, which if changing, would cause long run average costs to vary in the same direction as sales. For the computer industry, the falling price of hardware may be translated into declining long-run average costs, so that one measure of corporate efficiency would be the ability to contain costs or maintain reductions in cost of goods sold.

Barnett [23] set forth that innovations are a progression of ideas that are continuously adapted so that they represent successive socio-cultural change. In the microcomputer industry, personal computers became cheaper and lightweight. Yet, their stationary nature did not serve the purpose of mobile computing which was met initially by laptops followed by tablets. The linear model consisted of the successive changes to the personal computer in a sequence from R\&D to production engineering to marketing, while the shift to mobile computing assumed a nonlinear form in an alternate sequence from marketing to R\&D to production engineering. Nonlinear models underscore the uncertainties in the production process (Rosenberg [24]) and perceive innovation as a cluster of new products rather than a single product line (Storper [25]). The firm becomes a learning organization, with interaction among human elements resulting in systems of innovation (Lundvall [26]). Johnson et al. [27] coined the term disruptive innovation to describe the impact of some of the new products sold by technology-intensive firms. He set forth that they offered a new set of attributes which could only be valued by emerging markets separate from mainstream markets. Johnson et al. [27] felt that such disruptive innovations are frequently overlooked as new markets may not have the profit margins to provide acceptable growth rates to established firms. The integration of such innovation into mainstream product development could improve the economic returns of the firm, the main challenge being management's acceptance of the benefits of investing in disruptive innovations. The replacement of certain personal computers by smartphones and tablets is an example of low-end disruption. PC customers, at one time were satisfied with minimal functions for word processing, data processing and Internet access using wired systems. The disruption emanated from smartphones which performed all of these functions through wireless networks in a mobile computing environment. These additional product features resulted in the PC being relegated to shrinking markets, while smartphones moved up market with increasing profit margins.

\subsection{Firm Size}

In successive studies, firm size has been found to be the most powerful determinant of CEO compensation explaining up to $30 \%$ of the variation in CEO pay in both publicly-held and privately-owned firms. In a seminal 
paper, Murphy [28] declared, ...."the best documented stylized fact regarding CEO pay; CEO pay is higher at larger firms,” (Murphy [28]). Tosi et al. [29] provide the rationale for the importance of firm size setting forth that increasing size reduces risk and provides an alternate performance criterion to financial performance.

In early studies, Rosen [30] and Kostiuk [31] observed that a 10 percent pay increase resulted in a 3 percent increase in CEO pay. Brookman and Thistle [32] regressed CEO compensation on lagged stock returns, return on assets, the log of assets and leverage. Significant coefficients of $0.29-0.40$ were observed on the log of assets. In an examination of CEO compensation for firms with declining performance, Lin and Kuo [33] observed that firm size (measured as the log of assets) was the only variable that explained both total CEO compensation and CEO cash compensation at the 1\% level. Cole and Mehran [19] used sales rather than assets as their measure of firm size. Pay-size elasticities for public firms were robust to the Brookman and Thistle [32] result while significance was higher for privately-held firms. These results were robust across nine industry groups including construction and mining, primary manufacturing, other manufacturing, transportation, wholesale trade, retail trade, insurance and real estate, business services, professional services and public administration.

In the context of high-technology firms, given the paucity of literature on the explanatory variables influencing CEO compensation, we may state exploratory questions in lieu of hypotheses. In the context of firm size, the Tosi et al.'s [29] managerial power hypothesis may prevail with larger firms providing increasing compensation over smaller firms. Both Anderson et al. [34] and Shim et al. [35] found that firm size explained CEO performance in high-technology firms during the 1996-2003 time period. Anderson et al. [34] reason that larger firms hire better managers and in order to stay competitive pay higher wages. Shim et al. [35] found highly significant relationships between firm size and three separate measures of compensation for both high and low technology firms, suggesting that the influence of firm size on compensation is independent of industry effects. Accordingly, we may state the first hypothesis as:

Exploratory Question 1: Does firm size significantly explain the variation in CEO compensation?

\section{Research and Development Expenditure $\rightarrow$ Sales Growth $\rightarrow$ CEO Compensation}

Balkin et al. [36] subscribe to a resource-based view of the firm whereby chief executives are charged with the responsibility of maintaining the firm's ability to innovate. Innovation in high-technology firms is critical as a source of competitive advantage. It is manifested in the production of a stream of products, which may continuously improve a product line or achieve a higher level of technological advancement that renders competitive technologies obsolete (Tushman and Anderson [37]). It is funded by an ever-increasing amount of research and development expenditure. To sustain innovation, CEOs need to make risky decisions and should be compensated for assuming such risk (Finkelstein and Hambrick [38]). CEOs are exposed to the risk of early termination and adverse reputation if substantial investments in research and development do not yield desired results (Balkin et al. [36]). Agency theory recognizes the distinction between the goals of stockholders who encourage risk-taking to earn higher returns and managers as agents who are risk-averse to maintain job security. It follows that stockholders may encourage additional compensation for CEOs for bearing risk thereby linking innovation to CEO compensation. Callan and Thomas [20] observed that one and two-period lagged research and development expenditure significantly influenced executive compensation. Balkin et al. [36] found that innovations including patents and research and development expenditure significantly determined both short-term CEO compensation (base salary and bonus which are linked to obtaining patents and producing new products) and long-term compensation (stock option grants which are based upon the ability to harness short-term revenues from new products into sustained long-term investments which increase the stock price). Research and development provides higher significance if measured in conjunction with firm rating, reputation and operating performance. This study envisions an intervening link between innovations and sales growth for successful new products. Total revenue has been found to significantly influence CEO compensation, the rationale being that increasing revenue suggests increasing sales of the firms' products implying superior financial performance. O'Reilly and Main [5] obtained significant coefficients for revenues in their regression on diverse executive compensation measures including salary with other cash compensation and salary, bonus and stock option grants in three model specifications. However, as total revenue or net revenue (Callan and Thomas [20]) may be a proxy for firm size (Anderson et al., [34]; Cole and Mehran [19]), it may be more appropriate to employ revenue growth per year as an indicator of both new product and existing product performance.

Exploratory Question 2: Do innovations in the form of patents and research and development expenditure promote sales growth which in turn, increases basic and incentive CEO compensation? 


\subsection{Research and Development Expenditure $\rightarrow$ Stock Returns $\rightarrow$ CEO Compensation}

Intuitively, the path from Research and Development Expenditure $\rightarrow$ Stock Returns $\rightarrow$ CEO compensation suggests that investors in growing high technology firms seek stock returns rather than dividends, so that innovations are translated to rising stock prices. As stock returns act as a performance measure, CEO compensation, particularly in the form of stock option grants may be based upon rising stock returns. Balkin et al. [36] set forth that it is the CEO's responsibility to oversee a continuous flow of new products through the firm's production processes which, in the short-term will be valued on their technical merits, i.e. patents, but in the long-term, will afford the firm the competitive advantages reflected in stock price appreciation. Anderson et al. [34] observed that stock return was a significant predictor of CEO pay as measured by bonus pay, suggesting a more transient relationship between stock returns and performance in information technology firms.

Exploratory Question 3: Do innovations in the form of research and development expenditure promote stock returns which in turn, increases basic and incentive CEO compensation?

\subsection{Cost of Goods Sold $\rightarrow$ Operating Income $\rightarrow$ Net Income $\rightarrow$ CEO Compensation}

The literature relating financial statement measures to CEO compensation has found mixed support. On the one hand, Anderson et al. [34] and Balkin et al. [36] observed the significant influence of return on assets on CEO pay in technology firms, a general sample consisting of all firms in the ExecuComp database from 1993-2008 (Brookman and Thistle [32])), a general sample from 2007-2010 (Lin and Kuo, [33]), and privately-held firms (Cole and Mehran [19]) while on the other hand there was no link between earnings per share and CEO compensation (Garen [39]). The conflict may be due to the failure to trace the entire path from cost of goods sold to CEO pay. As Brunello et al. [40]) noted, the net income-to-CEO compensation link has theoretical basis in that net income or profit is an observable measure of firm performance. Likewise, Tosi et al. [29] presented a series of studies as supporting the relationship between return on equity and cash compensation (Belliveau et al., [41]; Finkelstein and Boyd [42]; Johnson [43]). Their own meta-analysis (Tosi et al., [29]) obtained significant predictions of CEO pay by both short-term and long-term return on equity. Yet, the link of operating income $\rightarrow$ net income or cost of goods sold $\rightarrow$ operating income has not been theorized. We maintain that it is the responsibility of the CEO to ensure operational efficiency in production, which suggests that the optimal allocation of resources in the manufacture of waves of new products or reductions in cost of goods sold over time. Reductions in cost of goods sold increases gross profit or in turn, operating income or earnings before interest and taxes. The query may be raised as to the reason for the lack of significance of earnings per share in the Garen [39] study. Is earnings per share not a measure of operational efficiency? We take issue with this contention, in that earnings per share may be distorted by selling, general and administrative expenses which are not factored into operating income. Therefore, operating income may be the more accurate estimate of operational efficiency.

Exploratory Question 4: Do reductions in cost of goods sold increase operating income which in turn, increases net income and positively influences CEO compensation?

\subsection{Creditworthiness}

Both Jensen and Meckling [4] and Amihud and Lev ([44] have suggested that CEOs may adjust their compensation to reduce the flow of cash to themselves. If residual cash flows in a particular year are low, CEOs may reduce their compensation which reduces the risk of financial distress and increases the probability that the CEO may be retained. Firms may even have loan covenants requiring the maintenance of minimum debt coverage ratios. Empirically, Cole and Mehran [19] obtained significant coefficients on Dun and Bradstreet's Credit Ratings upon regression with executive compensation. The corporate debt level may have other effects.

John and John [45] extended the Jensen and Meckling [4] and Amihud and Lev [44] positions by theorizing that firms seeking to reduce financial leverage may use fewer stock options and incentive pay as such action may encourage risk-taking by management. Such increasing indebtedness would be averse to the goals of debt holders. Anderson et al. [34] found empirical support for this conjecture in their regression of debt to asset ratio on stock options. Given the high risk of failure in technology, the ability to raise capital for future expansion may be compromised. As a start-up firm, the technology-intensive firm relies on venture capital, with future expansion needs being met by retained earnings.

Exploratory Question 5a: Does increasing indebtedness in the form of an increasing debt to asset ratio vary inversely with CEO compensation? 
Exploratory Question 5b: Does the ability to fund growth through retained earnings significantly explain the variation in CEO compensation?

\subsection{Age, Tenure, Education and Other Explanatory Variables}

Barro and Barro [46] used a quadratic specification for age arguing that age follows a life-cycle hypothesis with CEO pay increasing with age in a nonlinear fashion. This thesis draws on the work of Mayers and Smith [47] who found CEO age and experience varied with CEO compensation for insurance companies-a finding that was replicated for banks (Bliss and Rosen [48]) This position may be untenable in technology-intensive firms in which youthful CEOs with innovative product ideas may develop product ideas that resonate with customers. Google, Cisco, Facebook and Twitter are a few of the firms whose CEOs earned substantial wealth in a relatively short time due to the production of innovative new products and services. Such wealth is more prevalent through sudden increases in stock prices or stock options as a form of compensation may be expected to vary inversely with age. CEO salary, however, may follow a more traditional life-cycle pattern with salaries increasing directly with age. The managerial power hypothesis invests more power in tenured CEOs "to develop personal networks and power.”(Culpan et al. [49] p. 211) so that CEO compensation may be a function of political rather than economic variables (Ungson and Steers [50]). Human capital theory (Becker [51]) postulates that employee characteristics such as educational attainment increase earnings over a lifetime. Positive relationships between education and CEO compensation have been found in non-technology intensive industries (Chung and Pruitt [52]; Main, O’Reilly and Wade [9]), though there is a paucity of research in technology-intensive firms. However, the technical nature of new devices, the need to integrate hardware and software, and produce a stream of more technologically sophisticated phones, laptops and tablets suggests the need for increasing educational attainment.

Additional explanatory variables include the existence of a celebrity CEO or a founder who would be compensated at a higher level by virtue of the visibility they provide to the firm and in recognition of their contribution as founders. More subtle is the ability of a CEO to recognize the value of disruptive technologies and pioneer in their development. Accordingly, we include a subjective assessment of the CEO's ability to capitalize on such innovations in a timely fashion.

\section{Data and Methodology}

All firms listed on the NASDAQ from 1993-2011 were screened for inclusion in the sample. After exclusion of non-U.S. firms and those firms engaged exclusively in the marketing of technology such as advertising and radio and television, the final sample consisted of 431 firms. These firms were classified as producers of computer software, non-computer industrial machinery, semiconductors, electronic data processing services, semiconductors, computer hardware, computer peripherals, electrical products, retail computer software, electronic components and computer communications. Stock prices were extracted from the CRSP (Center for Research in Security Prices) database. COMPUSTAT acted as the source for financial statement data including total assets (measuring size), cost of goods sold, long-term debt, net income, operating income, research and development expense, revenue and stockholders' equity. The return on equity and debt to assets ratios were computed from the aforementioned net income, total assets and long-term debt data. Corporate reports of executive profiles provided demographic information on CEOs including age and tenure (measured in number of years), education (1 for an undergraduate degree and 2 for one or more graduate degrees), CEO-founder duality (a dichotomous variable assuming values of 0 for CEOs who were not founders or 1 for CEOs exhibiting CEO-founder duality) and celebrity status from news reports (CEOs whose names appeared in news reports were deemed celebrities scoring 1 while those whose names did not appear in news reports scored 0). Disruptive technology was measured as a dichotomous variable with values of 1 if a subjective assessment determined that a single product line displaced the competition or values of 0 all product lines coexisted with the competition. The compensation variables of salary, dollar value of stock option grants and total compensation were obtained from DEF 14A of the annual EDGAR filings with the Securities and Exchange Commission. Total compensation was the sum of all sources of compensation including salary, stock awards, stock option grants and unspecified long-term compensation payouts. Descriptive statistics and correlations of relevant variables are contained in Table 1.

Two types of exploratory questions were tested. Questions 1 and 5 assumed that explanatory variables remained exogenous while questions 2 - 4 assumed that variables were both exogenous and endogenous necessi- 
Table 1. Descriptive statistics and correlations.

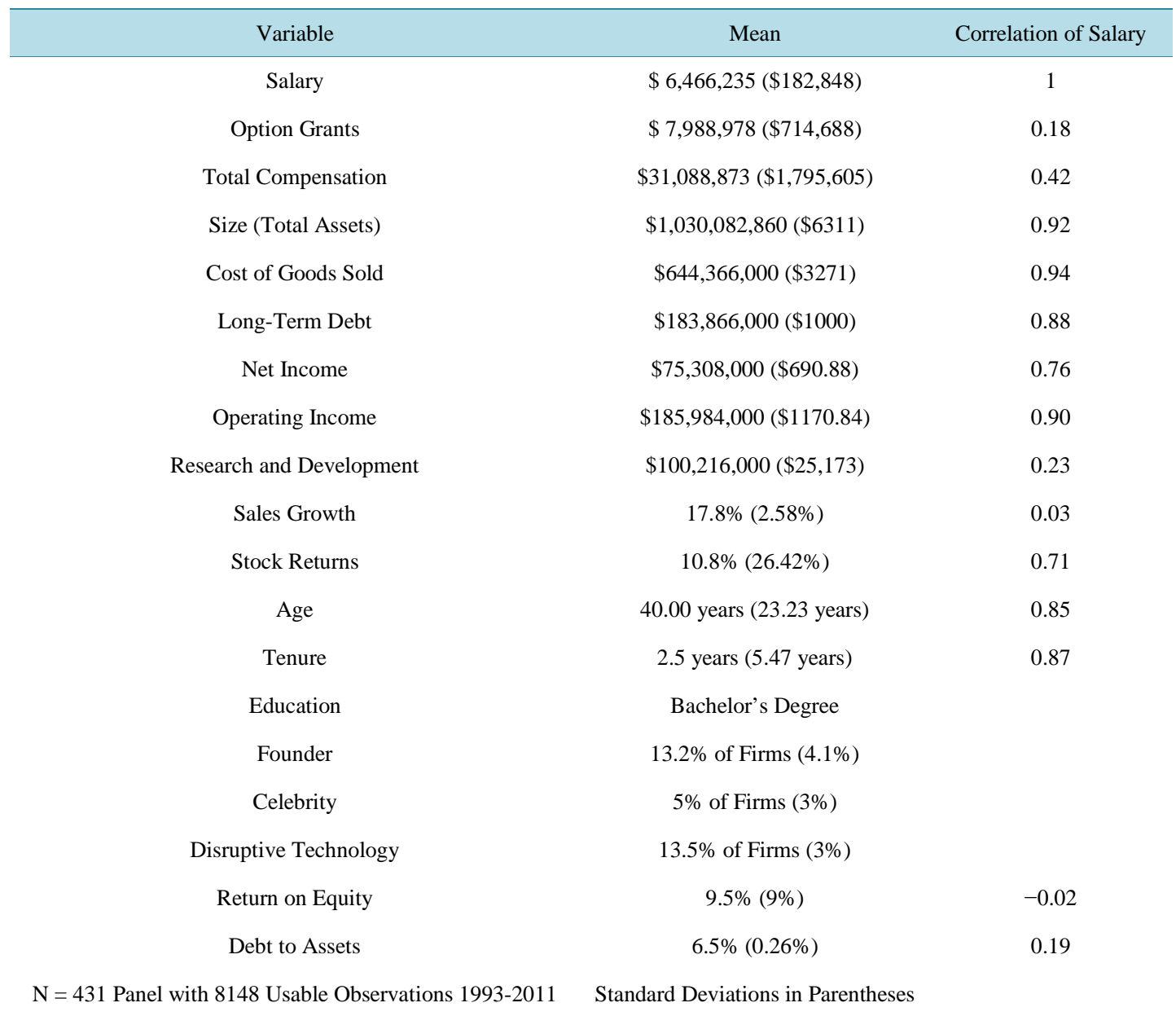

tating the employment of multiple regression to test the former category of questions and vector autoregression to examine the latter. The 3 multiple regressions may be represented as follows:

$$
\begin{gathered}
S A L=\alpha+\beta_{1} S I Z E+\beta_{2} D A+\beta_{3} G R O W T H+\beta_{4} A G E+\beta_{5} T E N+\beta_{6} E D U+\beta_{7} F O U+\beta_{8} C E L E+\beta_{9} D I S R \\
O P T=\alpha+\beta_{10} S I Z E+\beta_{11} D A+\beta_{12} G R O W T H+\beta_{13} A G E+\beta_{14} T E N+\beta_{15} E D U+\beta_{16} F O U+\beta_{17} C E L E+\beta_{18} D I S R \\
C O M P=\alpha+\beta_{19} S I Z E+\beta_{20} D A+\beta_{21} G R O W T H+\beta_{22} A G E+\beta_{23} T E N+\beta_{24} E D U+\beta_{25} F O U+\beta_{26} C E L E+\beta_{27} D I S R
\end{gathered}
$$

where

$S A L=$ Annual CEO salary

$O P T=$ CEO stock option grants

COMP = Total annual CEO compensation

SIZE $=$ Total assets

$D A=$ Debt to assets ratio

GROWTH = Ability to fund growth measured by stockholders' equity

$A G E=$ Age of $\mathrm{CEO}$ in years

$T E N=$ Tenure as CEO in years

EDUCATION = Scored as " 1 " for a bachelor's degree and " 2 " for a graduate degree

$F O U$ = CEO-FOUNDER duality; " 1 ” for a CEO who is a founder and " 0 ” for a CEO who is not a founder $C E L E=$ " 1 " for a CEO who is a celebrity and "0" for a CEO who is not a celebrity

$D I S R=$ " 1 ” for a firm with disruptive technology and "0” for a firm with non-disruptive technology

The vector autoregressions may be presented thus: 


$$
\begin{gathered}
\text { SALESGROWTH }=\alpha+\beta_{1} R D+\varepsilon \\
\text { SAL }=\alpha+\beta_{1} \text { SALESGROWTH } \\
\text { OPT }=\alpha+\beta_{1} \text { SALESGROWTH }+\varepsilon \\
\text { COMP }=\alpha+\beta_{1} \text { SALESGROWTH }+\varepsilon \\
\text { STOCKRETURNS }=\alpha+\beta_{1} R D+\varepsilon \\
\text { SAL }=\alpha+\beta_{1} \text { STOCKRETURNS }+\varepsilon \\
\text { OPT }=\alpha+\beta_{1} \text { STOCKRETURNS }+\varepsilon \\
\text { COMP }=\alpha+\beta_{1} \text { STOCKRETURNS }+\varepsilon \\
\text { OPERATINGINC }=\alpha+\beta_{1} C O G S+\varepsilon \\
\text { NETINC }=\alpha+\beta_{1} \text { OPERATINGINC }+\varepsilon \\
\text { SAL }=\alpha+\beta_{1} \text { NETINC }+\varepsilon \\
\text { OPT }=\alpha+\beta_{1} N E T I N C+\varepsilon \\
\text { COMP }=\alpha+\beta_{1} N E T I N C+\varepsilon
\end{gathered}
$$

where

SALESGROWTH = Annual Firm Revenue

$R D=$ Annual Research and Development Expenditure

OPERATINGINC = Annual Earnings Before Interest and Taxes (EBIT)

COGS = Annual Cost of goods sold

NETINC = Annual Net income.

\section{Results}

As reported in Table 2, Exploratory Question 1 was affirmed in that firm size exerted a significant influence on all three measures of CEO compensation (coefficient $=2.41, \mathrm{t}=8.27, \mathrm{p}<0.001$ for salary; coefficient $=9.63$. $\mathrm{t}$ $=7.69, \mathrm{p}<0.001$ for stock option grants; coefficient $=38, \mathrm{t}=12.33, \mathrm{p}<0.001$ for total compensation). Explo-

Table 2. Multiple regressions of the influence of size, demographic variables, disruptive technology, debt to assets and ability to fund growth on CEO compensation.

\begin{tabular}{cccc}
\hline Variable & Salary & Option Grants & Total Compensation \\
\hline Constant & $11.94^{* *}$ & $19.59^{* *}$ & 3.56 \\
Size & $2.41^{* *}$ & $9.63^{* *}$ & $38.00^{* *}$ \\
Age & $2.97^{* *}$ & $23.85^{* *}$ & $11.80^{*}$ \\
Tenure & $3.47^{* *}$ & 8.26 & $20.72^{* *}$ \\
Education & 1.67 & 4.83 & 9.56 \\
Founder CEO & $-5.25^{* *}$ & $29.08^{* *}$ & $-51.44^{* *}$ \\
Celebrity CEO & $3.94^{* *}$ & $20.74^{* *}$ & $48.26^{* *}$ \\
Disruptive & -1.47 & $14.51^{* *}$ & $29.04^{* *}$ \\
Debt to Assets & $-2.00^{*}$ & -13.93 & -6.85 \\
Growth Funding & $3.52^{* *}$ & 1.39 & $14.8^{*}$ \\
Number of Firms & 431 & & 0.07 \\
Adjusted R & 19.08 & 0.01 & \\
\hline
\end{tabular}

${ }_{\mathrm{p}}^{*}<0.05,{ }^{* *} \mathrm{p}<0.01,{ }^{* * *} \mathrm{p}<0.001$. 
ratory Question 2 was partly affirmed with research and development expenditure significantly explaining sales growth (coefficient $=46.91, \mathrm{t}=19.4, \mathrm{p}<0.001$ ) which in turn failed to influence any of the measures of compensation (see Table 3). Likewise, Exploratory Question 3 was partly affirmed with research and development expenditure being a significant explanatory variable of stock returns (coefficient $=0.09, \mathrm{t}=7.94, \mathrm{p}<0.001$ ). However, stock returns did not explain the variance in CEO remuneration. Exploratory Question 4 was also partly affirmed with net income significantly influencing all three measures of compensation (coefficient $=$ 13.45, $\mathrm{t}=4.60, \mathrm{p}<0.001$ for salary; coefficient $=76.32, \mathrm{t}=6.69, \mathrm{p}<0.001$ for stock option grants; coefficient $=$ $30.90, t=10.83, \mathrm{p}<0.001$ ), though such an effect failed to originate in cost containment through reduced cost of goods sold or higher operating income (see Table 3). Table 2 indicates that Exploratory Question 5a was affirmed with reductions in debt to assets significantly increasing salary (coefficient $=-2.0, t=-2.86, p<0.001$ ). Exploratory Question $5 \mathrm{~b}$ was also affirmed with the ability to fund growth significantly explaining both salary (coefficient $=3.52, \mathrm{t}=5.26, \mathrm{p}<0.001$ ) and total compensation (coefficient $=14.80, \mathrm{t}=2.1, \mathrm{p}<0.001$ ).

Additional explanatory variables including age, tenure, CEO as founder, CEO as celebrity and disruptive technology exhibited significant effects on compensation for the linear functional forms. Regressions of compensation on these variables assuming a linear specification are reported in Table 2. For a quadratic specification, education was significant (coefficient $=11.94, \mathrm{t}=2.87, \mathrm{p}<0.01$ ), as were CEO as founder (coefficient $=$ $8.28, \mathrm{t}=2.55, \mathrm{p}<0.05$ ), and CEO as celebrity (coefficient $=8.44, \mathrm{t}=2.58, \mathrm{p}<0.01$ ) with salary as the predictor variable.

\section{Conclusions}

This study finds a robust link between firm performance and CEO pay. CEOs of firms in the technology sector are rewarded with both base pay and incentive compensation for maintaining profitability, reducing debt and finding sources of funding. Firms in this sector are expected to produce a stream of new products which enhance sales growth and stock returns. Yet, the mere production of innovative products does not translate into higher compensation; the products must generate sufficient net income for CEOs to receive higher salary and incentive compensation. The finding of the critical role of net income in explaining CEO compensation is unique to this study. In addition, the uncertainty of acceptance of new products by customers may stimulate the need to reduce risk in new product development by limiting leverage. Intuitively, technology firms are often challenged to find

Table 3. Results of vector auto regressions of research and development expenditure, sales growth, stock returns, operating income and net income on CEO compensation.

\begin{tabular}{|c|c|}
\hline Path Coefficient & Significance \\
\hline Research $\rightarrow$ Sales Growth & $46.9^{* *}$ \\
\hline SalesGrowth $\rightarrow$ Salary & 0.52 \\
\hline SalesGrowth $\rightarrow$ Options & 0.46 \\
\hline SalesGrowth $\rightarrow$ Compensation & 0.86 \\
\hline Research $\rightarrow$ Stock Returns & $0.09^{* *}$ \\
\hline StockReturns $\rightarrow$ Salary & 0.79 \\
\hline StockReturns $\rightarrow$ Options & 0.30 \\
\hline StockReturns $\rightarrow$ Compensation & 0.48 \\
\hline Cost of Goods Sold $\rightarrow$ Operating Income & -0.01 \\
\hline Operating Income $\rightarrow$ Net Income & -0.05 \\
\hline Net Income $\rightarrow$ Salary & $13.45^{* * *}$ \\
\hline Net Income $\rightarrow$ Options & $76.32^{* * *}$ \\
\hline Net Income $\rightarrow$ Compensation & $30.90^{* * *}$ \\
\hline
\end{tabular}


capital continuously to fund growth as they are viewed as excessively risky by lenders. CEOs who are able to meet this challenge year-after-year are rewarded with higher salary and long-term incentive payouts. In the short-term, CEOs who position their firms to create disruptive technology which sustains competitive advantage benefit from higher stock option grants.

This study finds evidence to support the managerial power hypothesis as senior celebrity CEOs receive higher salary and long-term incentive compensation. However, the extent of managerial power may be limited.

Founder CEOs earn higher option grants, though this effect is nullified in total compensation by reduced salary and other long-term incentive payouts. Technology firms may not permit agency theory to exist. Given the intense competitiveness and large initial outlay for research and development to fund innovation in the typical technology firm, there may be insufficient funds to maintain agency theory's manifestations of pursuing risky projects at the expense of corporate long-term financial health.

This study updates the Anderson et al. [34] and Shim et al. [35] finding of the importance of firm size in explaining compensation in technology firms with our employment of a more current time period of 1993-2011 versus their use of 1996-2004 data. We use total assets as the measure of firm size in accordance with the literature (Brookman \& Thistle [32]; Lin \& Kuo [33]; Tosi et al. [29]). We concur with the Anderson et al. [34] observation that larger firms use competitive wages as a means to attract talent.

\section{References}

[1] Dong, M. and Ozkhan, A. (2008) Institutional Investors and Director Pay: An Empirical Study of UK Companies. Journal of Multinational Financial Management, 18, 16-29. http://dx.doi.org/10.1016/j.mulfin.2007.06.001

[2] Frydman, C. and Jenter, D. (2010) CEO Compensation, Annual Review of Financial Economics. Annual Reviews, 2, 75-102.

[3] Core, I., Holthausen, R.W. and Larker, D.R. (1999) Corporate Governance, Chief Executive Officer Compensation and Firm Performance. Journal of Financial Economics, 51, 371-406. http://dx.doi.org/10.1016/S0304-405X(98)00058-0

[4] Jensen, M.C. and Meckling, W. (1976) Theory of the Firm, Managerial Behavior, Agency Costs and Ownership Structure. Journal of Financial Economics, 3, 305-360. http://dx.doi.org/10.1016/0304-405X(76)90026-X

[5] O’Reilly, R.A. and Main, B.G.M. (2010) Economic and Psychological Perspectives on CEO Compensation: A Review and Synthesis. Industrial and Corporate Change, 19, 675-712. http://dx.doi.org/10.1093/icc/dtp050

[6] Abowd, J.M. and Kaplan, D.S. (1999) Executive Compensation: Six Questions That Need Answering. Journal of Economic Perspectives, 13, 145-168. http://dx.doi.org/10.1257/jep.13.4.145

[7] Devers, C.E., Cannell, A.A., Reilly, G.P. and Yoder, M.A. (2007) Executive Compensation: A Multidisciplinary Review of Recent Developments. Journal of Management, 33, 1016-1072. http://dx.doi.org/10.1177/0149206307308588

[8] Jensen, M.C. and Murphy, K.J. (1990) Performance Pay and Top Management Incentives. Journal of Political Economy, 98, 225-263. http://dx.doi.org/10.1086/261677

[9] Main, B.G.M., O’Reilly, C.A. and Wade, J.B. (1995) The CEO, the Board of Directors and Executive Compensation: Economic and Psychological Perspectives. Industrial and Corporate Change, 4, 293-332. http://dx.doi.org/10.1093/icc/4.2.293

[10] Ozkhan, N. (2007) Do Corporate Governance Mechanisms Influence CEO Compensation? An Empirical Investigation of UK Companies. Journal of Multinational Financial Management, 17, 349-364. http://dx.doi.org/10.1016/j.mulfin.2006.08.002

[11] Vafeas, N. (1999) Board Meeting Frequency and Firm Performance. Journal of Financial Economics, 53, $113-142$. http://dx.doi.org/10.1016/S0304-405X(99)00018-5

[12] He, L. and Conyon, M.J. (2003) Compensation Committees and CEO Compensation in US High-Technology Firms. Working Paper, Wharton School of Business, University of Pennsylvania, Philadelphia.

[13] Werner, S., Tosi, S. and Gomez-Mejia, L. (2005) Organizational Governance and Employee Pay: How Ownership Structure Affects the Firm's Compensation Strategy. Strategic Management Journal, 26, 377-384. http://dx.doi.org/10.1002/smj.452

[14] Cyert, R., Kang, S.H. and Kumar, P. (2002) Corporate Governance, Takeovers, and Top Management Compensation: Theory and Evidence. Management Science, 48, 453-469. http://dx.doi.org/10.1287/mnsc.48.4.453.205

[15] Goyal V.K. and Park, C.W. (2002) Board Leadership Structure and CEO Turnover. Journal of Corporate Finance, 8, 49-66. http://dx.doi.org/10.1016/S0929-1199(01)00028-1

[16] Borokovich, K.A., Brunarski, K.R. and Perrino, R. (1997) CEO Contracting and Anti-Takeover Amendments. Journal of Finance, 52, 1495-1517. http://dx.doi.org/10.1111/j.1540-6261.1997.tb01118.x 
[17] Fligstein, N. and Choo, J. (2005) Law and Corporate Governance. Annual Review of Law and Social Science, 1, 61-84.

[18] Kerr, J. and Bettis, R.A. (1987) Boards of Directors, Top Management Compensation and Shareholder Returns. Academy of Management Journal, 30, 645-664. http://dx.doi.org/10.2307/256153

[19] Cole, R.A. and Mehran, H. (2013) What Do We Know about Executive Compensation at Privately Held Firms? Federal Reserve Bank Staff Report No. 314, The Federal Reserve Bank of New York, New York.

[20] Callan, S.A. and Thomas, J.M. (2011) Executive Compensation, Corporate Social Responsibility, and Corporate Financial Performance: A Multi-Equation Framework. Corporate Social Responsibility and Environmental Management, 18, 332-351. http://dx.doi.org/10.1002/csr.249

[21] Fama, E.F. and French, K.R. (1993) Common Risk Factors in the Returns on Stocks and Bonds. Journal of Financial Economics, 33, 3-56. http://dx.doi.org/10.1016/0304-405X(93)90023-5

[22] Schumpeter, J.A. (1939) Business Cycles: A Theoretical, Historical, and Statistical Analysis of the Capitalist Process. McGraw-Hill, New York.

[23] Barnett, H.G. (1953) Innovation: The Basis of Cultural Change. McGraw-Hill, New York.

[24] Rosenberg, N. (1976) The Direction of Technological Change: Inducement Mechanisms and Focusing Devices. In: Rosenberg, N., Ed., Perspectives on Technology, Cambridge University Press, Cambridge, 108-125. http://dx.doi.org/10.1017/CBO9780511561313.007

[25] Storper, M. (1995) Regional Economies as Relational Assets. Unpublished Manuscript.

[26] Lundvall, B.A. (1995) The Social Dimension of the Learning Economy. Working Paper No 96-1, Aalborg University, Aalborg.

[27] Johnson, M., Christensen, C. and Hagermann, K. (2008) Reinventing Your Business Model. Harvard Business Review, 2-11.

[28] Murphy, K.J. (1999) Executive Compensation. In: Ashenfelter, O. and Card, D., Eds., Handbook of Labor Economics, Vol. 3, North Holland, Amsterdam, 2485-2563. http://dx.doi.org/10.1016/S1573-4463(99)30024-9

[29] Tosi, H., Werner, S., Katz, J. and Gomez-Mejia, L. (2000) How Much Does Performance Matter? A Meta-Analysis of CEO Pay Studies. Journal of Management, 26, 301-339. http://dx.doi.org/10.1177/014920630002600207

[30] Rosen, S. (1982) Authority, Control and the Distribution of Earnings. Bell Journal of Economics, 13, 311-323. http://dx.doi.org/10.2307/3003456

[31] Kostiuk, P. (1990) Firm Size and Executive Compensation. Journal of Human Resources, 25, 90-105. http://dx.doi.org/10.2307/145728

[32] Brookman, J.T. and Thistle, P.D. (2013) Managerial Compensation: Luck, Skill or Labor Markets? Journal of Corporate Finance, 21, 252-268. http://dx.doi.org/10.1016/j.jcorpfin.2013.03.001

[33] Lin, D. and Kuo, H. (2013) Chief Executive Compensation: An Empirical Study of Fat Cat CEOs. The International Journal of Business and Finance Research, 7, 27-42.

[34] Anderson, M.C., Banker, R.D. and Ravindran, S. (2000) Executive Compensation in the Information Technology Industry. Management Science, 46, 530-547. http://dx.doi.org/10.1287/mnsc.46.4.530.12055

[35] Shin, E., Lee, J. and Kajoo, I. (2009) CEO Compensation and US High and Low-Tech Firms’ Corporate Performance. Contemporary Management Research, 5, 93-106.

[36] Balkin, D.B., Markman, G.D. and Gomez-Mejia, L.R. (2000) Is CEO Pay in High-Technology Firms Related to Innovation? Academy of Management Journal, 43, 1118-1129. http://dx.doi.org/10.2307/1556340

[37] Tushman, M.L. and Anderson, P. (1986) Technological Discontinuities and Organizational Environments. Administrative Science Quarterly, 31, 439-465. http://dx.doi.org/10.2307/2392832

[38] Finkelstein, S. and Hambrick, D.C. (1996) Top Executives and Their Efforts on Organizations. West Publishing, Minneapolis.

[39] Garen, J.E. (1994) Executive Compensation and Principal-Agent Theory. Journal of Political Economy, 102, 11751199. http://dx.doi.org/10.1086/261967

[40] Brunello, G., Graziano, C. and Perigi, B. (2001) Executive Compensation and Firm Performance in Italy. International Journal of Industrial Organization, 19, 133-161. http://dx.doi.org/10.1016/S0167-7187(99)00026-0

[41] Belliveau, M.A., O’Reilly, C.A. and Wade, J.B. (1996) Social Capital at the Top: Effects of Social Similarity and Status on CEO Compensation. Academy of Management Journal, 39, 1568-1593. http://dx.doi.org/10.2307/257069

[42] Finkelstein, S. and Boyd, B.K. (1998) How Much Does the CEO Matter? The Role of Managerial Discretion in the Setting of CEO Compensation. Academy of Management Journal, 37, 1079-1108.

[43] Johnson, B. (1982) Executive Compensation: Size, Profit and Cost in the Electric Utility Industry. Unpublished Doctoral Dissertation, Florida State University, Tallahassee. 
[44] Amihud, Y. and Lev, B. (1981) Risk Reduction as a Managerial Motive by Conglomerate Managers. Bell Journal of Economics, 12, 605-617. http://dx.doi.org/10.2307/3003575

[45] John, T. and John, K. (1993) Top Management Compensation and Capital Structure. Journal of Financial Economics, 48, 949-974.

[46] Barro, J.R. and Barro, R.J. (1990) Pay, Performance and Turnover of Bank CEOs. Journal of Labor Economics, 8, 448-481. http://dx.doi.org/10.1086/298230

[47] Mayers, D. and Smith, C.W. (1992) Executive Compensation in the Life Insurance Industry. Journal of Business, 65, 51-74. http://dx.doi.org/10.1086/296557

[48] Bliss, R.T. and Rosen, R.J. (2001) CEO Compensation and Bank Mergers. Journal of Financial Economics, 61, 107138. http://dx.doi.org/10.1016/S0304-405X(01)00057-5

[49] Culpan, R., Murti, V.N. and Culpan, O. (1992) Determinants of CEO Pay in Service Industry Firms. Group and Organization Management, 17, 210-217. http://dx.doi.org/10.1177/1059601192172007

[50] Ungson, G.R. and Steers, R.M. (1984) Motivation and Politics in Executive Compensation. Academy of Management Review, 9, 313-323.

[51] Becker, G. (1974) Human Capital: A Theoretical and Empirical Analysis, with Special Reference to Education. University of Chicago Press, Chicago.

[52] Chung, K.H. and Pruitt, S.W. (1996) Executive Ownership, Corporate Value and Executive Compensation: A Unifying Framework. Journal of Banking and Finance, 20, 1135-1159. http://dx.doi.org/10.1016/0378-4266(95)00039-9 
Scientific Research Publishing (SCIRP) is one of the largest Open Access journal publishers. It is currently publishing more than 200 open access, online, peer-reviewed journals covering a wide range of academic disciplines. SCIRP serves the worldwide academic communities and contributes to the progress and application of science with its publication.

Other selected journals from SCIRP are listed as below. Submit your manuscript to us via either submit@scirp.org or Online Submission Portal.
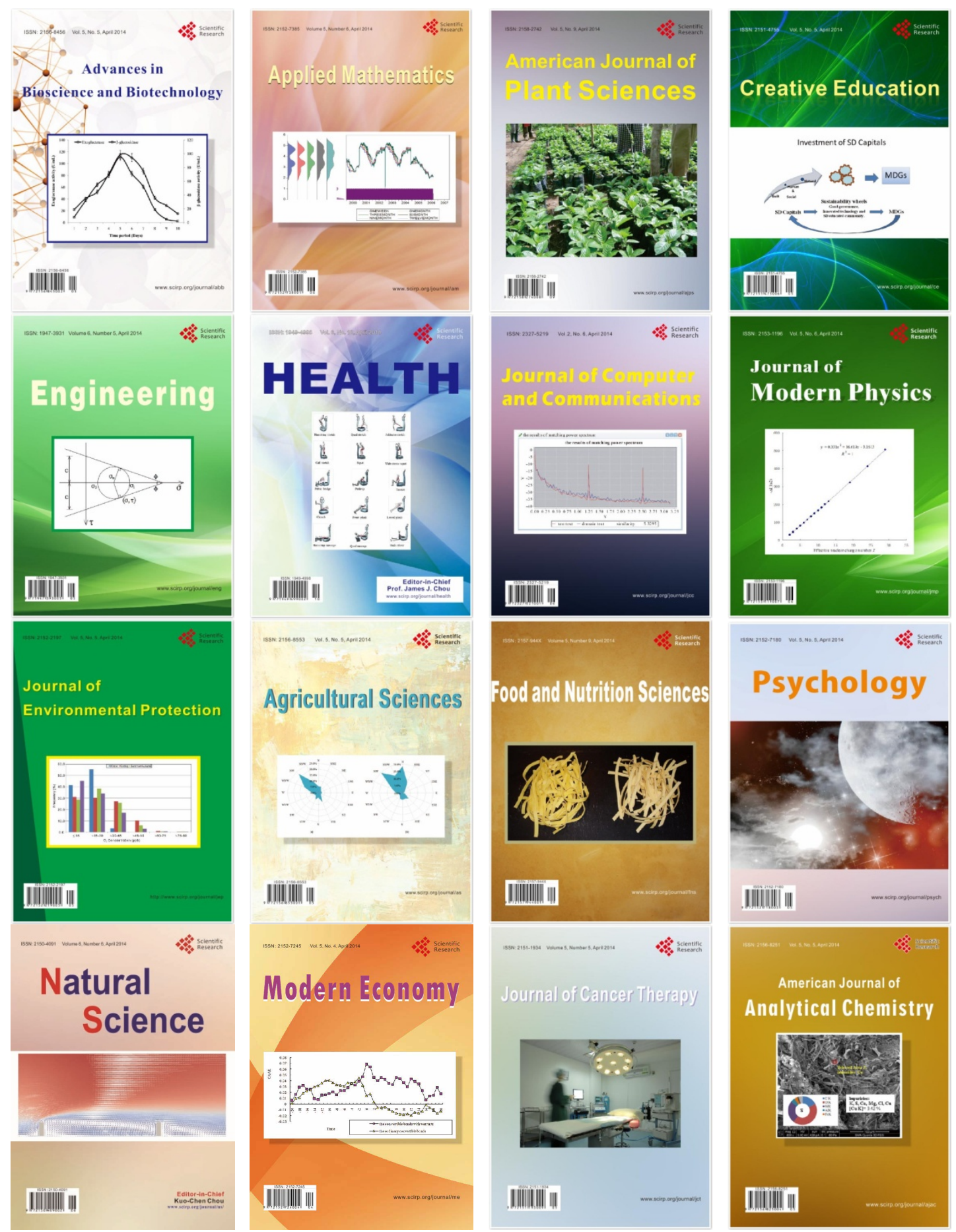